\title{
Meta-analysis of grain yield QTL identified during agricultural drought in grasses showed consensus
}

\author{
BP Mallikarjuna Swamy, Prashant Vikram, Shalabh Dixit, HU Ahmed and Arvind Kumar ${ }^{*}$
}

\begin{abstract}
Background: In the last few years, efforts have been made to identify large effect QTL for grain yield under drought in rice. However, identification of most precise and consistent QTL across the environments and genetics backgrounds is essential for their successful use in Marker-assisted Selection. In this study, an attempt was made to locate consistent QTL regions associated with yield increase under drought by applying a genome-wide QTL metaanalysis approach.

Results: The integration of 15 maps resulted in a consensus map with 531 markers and a total map length of 1821 CM. Fifty-three yield QTL reported in 15 studies were projected on a consensus map and meta-analysis was performed. Fourteen meta-QTL were obtained on seven chromosomes. MQTL $L_{1.2}, M_{Q} T_{1.3}, M Q T L_{1.4}$, and $M Q T L_{12.1}$ were around $700 \mathrm{~kb}$ and corresponded to a reasonably small genetic distance of 1.8 to $5 \mathrm{cM}$ and they are suitable for use in marker-assisted selection (MAS). The meta-QTL for grain yield under drought coincided with at least one of the meta-QTL identified for root and leaf morphology traits under drought in earlier reports. Validation of majoreffect QTL on a panel of random drought-tolerant lines revealed the presence of at least one major QTL in each line. $D T Y_{12.1}$ was present in $85 \%$ of the lines, followed by $D T Y_{4.1}$ in $79 \%$ and $D T Y_{1.1}$ in $64 \%$ of the lines. Comparative genomics of meta-QTL with other cereals revealed that the homologous regions of $M Q T L_{1.4}$ and $M Q T L_{3.2}$ had QTL for grain yield under drought in maize, wheat, and barley respectively. The genes in the meta-QTL regions were analyzed by a comparative genomics approach and candidate genes were deduced for grain yield under drought. Three groups of genes such as stress-inducible genes, growth and development-related genes, and sugar transport-related genes were found in clusters in most of the meta-QTL.

Conclusions: Meta-QTL with small genetic and physical intervals could be useful in Marker-assisted selection individually and in combinations. Validation and comparative genomics of the major-effect QTL confirmed their consistency within and across the species. The shortlisted candidate genes can be cloned to unravel the molecular mechanism regulating grain yield under drought.
\end{abstract}

\section{Background}

Drought is a severe abiotic stress that affects the production and productivity of rice. Drought stress at the reproductive stage is the most devastating [1,2]. Because of the ongoing process of climate change, the rainfall pattern has become more irregular in the cropping season, causing widespread drought in rice-growing areas, which results in severe yield losses [3,4]. The development of drought-tolerant varieties that maintain good yield under drought is a priority area of rice research for sustainable rice production.

\footnotetext{
* Correspondence: a.kumar@cgiar.org

International Rice Research Institute, DAPO Box 7777, Metro Manila, Philippines
}

Marker-assisted mapping and introgression of majoreffect QTL for grain yield under drought could be an efficient and fast-track approach for breeding drought-tolerant rice varieties [5]. However, the successful use of QTL in marker-assisted selection depends on their effect and consistency across genetic backgrounds and environments. Most of the QTL for grain yield under drought have been mapped against a single genetic background in early-segregating generations $\left(\mathrm{F}_{3}, \mathrm{BC}_{2}\right.$, and $\left.\mathrm{BC}_{2} \mathrm{~F}_{2}\right)$ evaluated in a limited number of environments. Such QTL may not provide a consistent effect because of variation in the genetic background and environment. Additionally, the QTL may not be transferrable to other backgrounds because of unfavorable epistatic interactions resulting in reduced or even no 
effects in a new genetic background [6,7]. Considering all these facts, it is difficult to predict the usefulness of QTL for MAS based only on their performance in an individual genetic background in any particular study.

A more efficient way to select QTL for MAS is to compare the identified QTL with earlier reported studies for their consistency of location and effect across genetic backgrounds and environments. Consistently identified QTL at the same chromosomal location, explaining high phenotypic variance and having a major effect on a trait, can be effectively used in MAS [8-10].

QTL meta-analysis is an approach to identify consensus QTL across studies, to validate QTL effects across environments/genetic backgrounds, and also to refine QTL positions on the consensus map [11]. QTL meta-analysis requires independent QTL for the same trait obtained from different populations, different locations, or different environmental conditions [11]. The consistent QTL identified by meta-analysis for a set of QTL at a confidence interval (CI) of 95\% are called meta-QTL (MQTL). The meta-QTL with the smallest CI and having a consistent and large effect on a trait are useful in MAS. In plants, the concept of meta-analysis has been applied to the analysis of QTL/genes for blast resistance [12], root traits and drought tolerance in rice $[9,10]$, lint fiber length in cotton [13], cyst nematode resistance in soybean [14], fusarium head blight resistance in wheat [15], flowering time [16], drought tolerance in maize [17], and disease resistance in cocoa [18].

QTL validation is another approach to confirm the effect of QTL across different genetic backgrounds. QTL regions harbor many genes; among them, a few key genes could be more important in the regulation of a complex trait. Meta-QTL regions with refined positions are more accurate for short-listing of candidate genes. The common candidate genes short-listed across the meta-QTL are more likely candidates that regulate yield [9].

In this study, QTL meta-analysis was carried out for yield QTL under drought to develop a consensus map and to identify consensus yield QTL under drought with the objective to provide markers of MQTL with high effects and small confidence intervals for possible use in MAS or for fine-mapping QTL for gene discovery. Also, markers linked to 12 major QTL for grain yield were validated on a set of random drought-tolerant lines, including landraces and improved drought breeding lines developed at IRRI, to know the frequency of their universal presence. Further, a comparative genomics approach was used to identify the homologous regions of MQTL in other cereal crops such as maize, sorghum, wheat, and barley (http://www.gramene.org/,http://www.maizegdb. org/, http://www.graingenes.org).

\section{Materials and methods Meta-QTL analysis}

Three steps were employed for the identification of a consensus QTL for grain yield under drought. First, in a bibliographic review, reliable data on QTL for yield per plant were compiled. Second, a consensus map was created and on this map the QTL of individual studies was projected. In the third step, a meta-analysis was performed on QTL clusters to identify the consensus MQTL.

\section{Bibliographic review and synthesis of yield QTL data}

QTL information was collected from published reports involving mapping of QTL for grain yield under drought. There were 15 reports of a QTL mapping for grain yield under drought. The details of the parents used in developing the mapping population, size of the mapping population, markers used, and yield QTL identified are given in Table 1. In all, 53 QTL were reported for yield.

\section{Development of a consensus map}

A consensus genetic map was constructed and metaanalysis was performed using Biomercator v2.0 (http:// www.genoplante.com/). The rice genetic linkage map of Temnykh et al. [19] was used as a reference map, on which the markers of 15 studies were projected to develop a consensus map. Chromosomes connected with fewer than two common markers to the reference map were excluded before the creation of the consensus map. Inversions of marker sequences were filtered out by discarding inconsistent loci with the exception of very closely linked markers. After the integration of all maps, the consensus map contained 531 markers, including SSR, RFLP, AFLP markers, and genes. The consensus map covered a total length of $1821 \mathrm{cM}$, with an average distance of $3.5 \mathrm{cM}$ between markers.

\section{QTL projections}

For all studies, the 95\% confidence intervals of initial QTL on their original maps were estimated using the approach described by Darvasi and Soller [20]:

$$
\mathrm{CI}=\frac{530}{\mathrm{NR}^{2}}
$$

Where $\mathrm{N}$ is the population size and $\mathrm{R}^{2}$ the proportion of the phenotypic variance explained by the QTL. The CI was re-estimated to control the heterogeneity of CI calculation methods across studies. Projection of QTL positions was performed by using a simple scaling rule between the original QTL flanking marker interval and the corresponding interval on the consensus chromosome. For a given QTL position, the new CI on the consensus linkage group was approximated with a 
Table 1 Details of mapping studies undertaken for grain yield under drought QTL

\begin{tabular}{|c|c|c|c|c|c|c|c|c|}
\hline $\begin{array}{l}\text { S. } \\
\text { no. }\end{array}$ & Parents used in crossing & $\begin{array}{l}\text { Mapping } \\
\text { population }\end{array}$ & $\begin{array}{l}\text { Population } \\
\text { size }\end{array}$ & $\begin{array}{l}\text { Number of } \\
\text { markers }\end{array}$ & Markers used & $\begin{array}{l}\text { Number of locations used for } \\
\text { phenotyping }\end{array}$ & $\begin{array}{l}\text { Yield QTL } \\
\text { identified }\end{array}$ & References \\
\hline 1 & $\begin{array}{c}\text { CTM9993-5-10-1 } \times \text { IR62266- } \\
42-6-2\end{array}$ & $\mathrm{DH}$ & 154 & 280 & AFLP, RFLP, SSR & 2 & 4 & {$[37]$} \\
\hline 2 & $\begin{array}{c}\text { CTM9993-5-10-1 } \times \text { IR62266- } \\
42-6-2\end{array}$ & $\mathrm{DH}$ & 154 & 315 & AFLP, RFLP, SSR & 1 & 7 & [1] \\
\hline 3 & Zhenshan 97 × IRAT109 & RIL & 180 & 245 & SSR & 2 & 4 & [38] \\
\hline 4 & Zhenshan 97B $\times$ IRAT109 & RIL & 187 & 213 & SSR & 2 & 2 & [39] \\
\hline 5 & Zhenshan 97 × IRAT109 & RIL & 180 & 245 & SSR & 2 & 5 & [40] \\
\hline 6 & IR20 × Nootripathu & RIL & 150 & 51 & SSR & 1 & 2 & [22] \\
\hline 7 & Bala × Azucena & RIL & 177 & 163 & $\begin{array}{l}\text { SSR, AFLP, RFLP, BAC } \\
\text { markers }\end{array}$ & 1 & 4 & [41] \\
\hline 8 & $\begin{array}{c}\text { CTM9993-5-10-1 } \times \text { IR62266- } \\
42-6-2\end{array}$ & $\mathrm{DH}$ & 220 & 315 & AFLP, RFLP, SSR & 3 & 1 & {$[42]$} \\
\hline 9 & Vandana $\times$ Way Rarem & $\mathrm{F}_{3: 4,}, \mathrm{BC}_{2}$ & 436 & 126 & SSR & 2 & 3 & [5] \\
\hline 10 & Apo $\times$ Swarna & $\mathrm{BC}_{1}, \mathrm{BC}_{2}, \mathrm{BC}_{3}$ & 301 & 293(BSA) 13(WG) & SSR & 2 & 4 & {$[2]$} \\
\hline 11 & N22 × Swarna & $F_{3: 4}$ & 292 & $140(\mathrm{BSA}) 17(\mathrm{WG})$ & SSR & 2 & 4 & [23] \\
\hline 12 & $\mathrm{~N} 22 \times$ MTU1010 & $F_{3: 4}$ & 362 & 140(BSA) 125 & SSR & 2 & 5 & [23] \\
\hline 13 & $\mathrm{~N} 22 \times \mathrm{IR} 64$ & $F_{3: 4}$ & 289 & $140(\mathrm{BSA}) 13(\mathrm{WG})$ & SSR & 2 & 4 & [23] \\
\hline 14 & IR77298-14-1-2 × IR64 & $\mathrm{BC}_{1}, \mathrm{BC}_{2}, \mathrm{BC}_{3}$ & 288 & 18 & SSR & 3 & 3 & $\begin{array}{c}\text { IRRI, } \\
\text { Unpublished }\end{array}$ \\
\hline 15 & IR55419-04 × Way Rarem & RIL & 158 & 3 & SSR & 2 & 1 & $\begin{array}{c}\text { IRRI, } \\
\text { Unpublished }\end{array}$ \\
\hline
\end{tabular}

$\overline{B S A}=$ bulk segregant analysis; $W G=$ whole genotyping; $A F L P=$ amplified fragment length polymorphism; RFLP =restricted fragment length polymorphism, SSR $=$ simple sequence repeats, $B A C=$ bacterial artificial chromosome 
Gaussian distribution around the most likely QTL position. All projections of QTL onto the consensus map were performed using the Biomercator (2.0) (http:// www.genoplante.com/).

\section{Meta-analysis}

Meta-analysis was performed on the QTL clusters on each chromosome using Biomercator (2.0) (http://www. genoplante.com). The Akaike Information Criterion (AIC) was used to select the QTL model on each chromosome [21]. According to this, the QTL model with the lowest AIC value is considered a significant model indicating the number of meta-QTL. QTL meta-analysis requires independent QTL for the same trait obtained from different plant populations, different locations, or different environmental conditions [11].

\section{QTL validation Genotyping}

All molecular marker work was conducted in the Gene Array and Molecular Marker Analysis (GAMMA) Laboratory, Plant Breeding, Genetics and Biotechnology (PBGB) division, IRRI. For DNA extraction, freeze-dried samples were used. Freeze-dried leaf samples were cut in eppendorf tubes and ground through a GENO grinder. Extraction was carried out by the modified CTAB method. DNA samples were stored in 2-mL deep-well plates (Axygen Scientific, California, USA). DNA samples were quantified on $0.8 \%$ agarose gel and concentration adjusted to approximately $25 \mathrm{ng} \mu \mathrm{L}^{-1}$. PCR amplification was done with a $15-\mu \mathrm{L}$ reaction mixture having $40 \mathrm{ng}$ DNA, $1 \times$ PCR buffer, $100 \mu \mathrm{M}$ dNTPs, $250 \mu \mathrm{M}$ primers, and 1 unit Taq polymerase enzyme. The PCR profiles started with an initial denaturation of DNA at $94^{\circ} \mathrm{C}$ for 5 minutes, followed by 35 amplification cycles of denaturation at $94^{\circ} \mathrm{C}$ for 1 minute, annealing temperatures varied from $55^{\circ} \mathrm{C}$ to $58^{\circ} \mathrm{C}$ for 45 seconds based on the primer, extension at $72^{\circ} \mathrm{C}$ for 1 minute and final extension at $72^{\circ} \mathrm{C}$ for 7 minutes. The PCR products were resolved on $8 \%$ nondenaturing polyacrilamide gels (PAGE). The gels were scored taking respective QTL donor alleles as reference band and scores were used for QTL validation. The details of the peak markers of the 12 major effect QTL are given in Additional File 1.

Twelve major effect drought grain yield QTL were validated on a panel of 92 drought tolerant lines consisting of traditional drought tolerant donors, drought tolerant breeding lines developed through conventional breeding approaches and random high yielding lines under drought from QTL mapping populations. The peak marker of all the twelve major effect QTL were amplified on the drought panel lines. The lines were scored taking QTL donor allele as a base. The list of lines is given in the Additional File 2.

\section{Gene content analysis}

The 14 meta-QTL were analyzed for gene content to know the presence of genes and gene clusters responsible for drought. A comparative genomics approach was followed to analyze the genes present in meta-QTL. Gene content was noted based on annotated data of homologous regions in Nipponbare using RAP, Build5 (http://rapdb.dna.affrc.go.jp/download/index.html). It is assumed that the genes identified in Nipponbare regions are homologous and collinear to those underlying the yield QTL under drought mapped in different studies involving different donors and recipients.

\section{Comparative genomics to identify homologous regions in cereals}

A comparative genomics approach was followed to identify homologous regions between rice and maize using the genomic databases (http://www.gramene.org). Homologous regions identified were checked for the presence of drought grain yield QTL of maize (http:// www.maizegdb.org). In sorghum, wheat, and barley, grain yield QTL reported were collected from a literature survey and these were compared with the metaQTL using the comparative maps available in the Gramene database (http://www.gramene.org).

\section{Results and discussion}

\section{Overview of QTL and development of a consensus map}

In the 15 populations of rice screened for drought tolerance to map QTL, population size ranged from 150 [22] to 436 lines [5]. The number of markers used ranged from 13 to 315 [1,23]. The number of locations for phenotyping varied from 1 to 3 . From the 15 studies, 53 yield QTL were reported, which were distributed on all the chromosomes except chromosome 11 (Table 1). The number of QTL per population ranged from 1 to 7 . The proportion of QTL per chromosome ranged from one QTL each on chromosomes 5 and 7 to 18 yield QTL on chromosome 1. The distribution of yield QTL on different chromosomes showed that chromosomes 1, 2, and 10 have the highest number, 18,7 , and 7 QTL, respectively (Figure 1). The phenotypic variance of the initial QTL varied from $3.2 \%$ to $40 \%$ and the confidence interval of the markers varied from 2 to $30 \mathrm{cM}$. The rice genetic map of Temnykh et al. [19] was used as a reference map to develop a consensus map as this is a widely used genetic map of rice and it contained most of the markers used in the different studies. The consensus map consisted of 531 markers with a total map length of $1821 \mathrm{cM}$. The average distance between the markers was $3.5 \mathrm{cM}$, thus enabling the identification of a precise location of QTL. There were very few marker inversions in the consensus map, which were discarded from the final map and further analysis. 


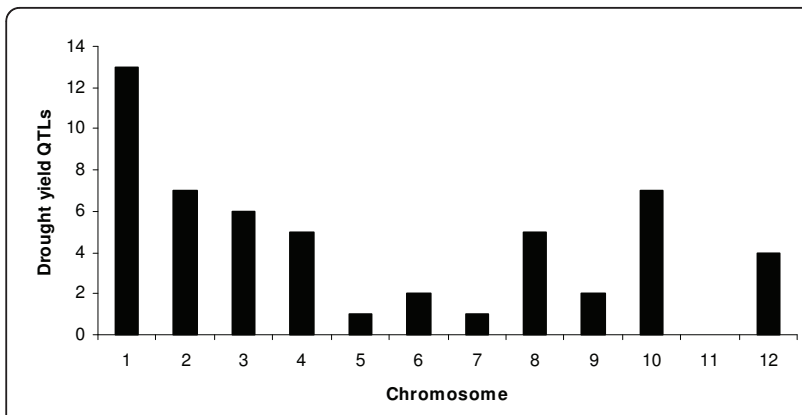

Figure 1 Distribution of grain yield QTL on rice chromosomes The bar diagram depicts the frequency of drought grain yield QTLS on rice chromosomes

\section{Meta-analysis and QTL validation}

It is widely believed that QTL are accurate and can be positioned onto chromosomal locations by molecular mapping $[24,25]$. However, their complex nature and context dependency in different genetic backgrounds and environments are constraints in identifying their precise location. The identification of the most accurate and precise major-effect QTL across genetic backgrounds and environments is a prerequisite for the successful use of QTL in MAS. Meta-analysis of QTL identified in different studies helps to identify the most precise and concise QTL, which can be further pursued for MAS or the identification of candidate genes. In our study, we attempted to identify the meta-QTL for grain yield under drought by genome-wide meta-analysis. From a bibliographic survey, a total of 53 QTL were short-listed for grain yield under drought from $15 \mathrm{stu}-$ dies. All 53 QTL were projected on a consensus map. The chromosomal regions with only one QTL were not considered for meta-analysis since meta-analysis by definition involves more than one QTL. Thus, 38 QTL were used for meta-analysis and meta-QTL were short-listed based on the Akaike Information Criterion (AIC). Accordingly, the QTL model with the lowest AIC value was considered a significant model indicating the number of meta-QTL. The number of meta-QTL along with their AIC values and confidence intervals are given in Table 2. In total, 14 independent meta-QTL were

Table 2 Meta-QTL for yield under drought identified by meta-analysis

\begin{tabular}{|c|c|c|c|c|c|c|c|c|c|c|c|c|c|}
\hline $\begin{array}{l}\text { S. } \\
\text { no. }\end{array}$ & MQTL & Chromosome & $\begin{array}{l}\text { QTL } \\
\text { region }\end{array}$ & $\begin{array}{c}\text { AIC } \\
\text { value }\end{array}$ & $\begin{array}{c}\text { QTL } \\
\text { model }\end{array}$ & $\begin{array}{c}\text { No of } \\
\text { initial } \\
\text { QTL }\end{array}$ & $\begin{array}{l}\text { Mean } \\
\text { phenotypic } \\
\text { variance of } \\
\text { the QTL }\end{array}$ & $\begin{array}{l}\text { Mean } \\
\text { initial } \\
\mathrm{Cl} \\
\text { (cM) }\end{array}$ & $\begin{array}{l}\text { MQTL } \\
\text { CI } \\
(95 \%) \\
\text { (cM) }\end{array}$ & $\begin{array}{l}\text { Physical } \\
\text { length } \\
\text { of MQTL } \\
\text { (Mb) }\end{array}$ & $\begin{array}{l}\mathrm{kb} / \\
\mathrm{cM}\end{array}$ & $\begin{array}{l}\text { Coefficient of } \\
\text { reduction in } \\
\text { length from } \\
\text { mean initial QTL } \\
\text { to MQTL }\end{array}$ & $\begin{array}{l}\text { MQTL } \\
\text { rank for } \\
\text { MAS/fine } \\
\text { mapping }\end{array}$ \\
\hline 1 & $\mathrm{MQTL}_{1.1}$ & 1 & $\begin{array}{l}\text { RZ276- } \\
\text { RM488 }\end{array}$ & 146.2 & 4 & 2 & 16 & 7.50 & 11.50 & 1.14 & 103.1 & 0.7 & \\
\hline 2 & $\mathrm{MQTL}_{1.2}$ & 1 & $\begin{array}{l}\text { RM543- } \\
\text { RM212 }\end{array}$ & & & 3 & 24 & 5.20 & 4.53 & 0.27 & 60.3 & 1.1 & 2 \\
\hline 3 & $\mathrm{MQTL}_{1.3}$ & 1 & $\begin{array}{l}\text { RM315- } \\
\text { RM472 }\end{array}$ & & & 2 & 16 & 17.80 & 6.30 & 0.16 & 183.4 & 2.8 & 4 \\
\hline 4 & $\mathrm{MQTL}_{1.4}$ & 1 & $\begin{array}{l}\text { RG109- } \\
\text { RM431 }\end{array}$ & & & 5 & 12 & 7.60 & 2.40 & 0.36 & 151.5 & 3.2 & 5 \\
\hline 5 & $\mathrm{MQTL}_{2.1}$ & 2 & $\begin{array}{l}\text { RM452- } \\
\text { RM521 }\end{array}$ & 62.7 & 4 & 3 & 12 & 10.50 & 5.28 & 1.24 & 229.8 & 2.0 & \\
\hline 6 & $\mathrm{MQTL}_{2.2}$ & 2 & $\begin{array}{l}\text { RM526- } \\
\text { RM497 }\end{array}$ & & & 2 & 6 & 12.00 & 11.50 & 2.36 & 110.7 & 1.0 & \\
\hline 7 & $\mathrm{MQTL}_{3.1}$ & 3 & $\begin{array}{l}\text { RG104- } \\
\text { RM523 }\end{array}$ & 45.2 & 3 & 3 & 13 & 5.40 & 17.43 & 0.84 & 47.7 & 0.3 & \\
\hline 8 & $\mathrm{MQTL}_{3.2}$ & 3 & $\begin{array}{l}\text { RM520- } \\
\text { RM16030 }\end{array}$ & & & 2 & 20 & 10.30 & 3.40 & 0.98 & 488.0 & 16.6 & 3 \\
\hline 9 & $\mathrm{MQTL}_{4.1}$ & 4 & $\begin{array}{l}\text { RM273- } \\
\text { RM252 }\end{array}$ & 45.3 & 3 & 3 & 9 & 8.40 & 3.98 & 1.32 & 338.2 & 2.1 & \\
\hline 10 & $\mathrm{MQTL}_{8.1}$ & 8 & $\begin{array}{l}\text { RM337- } \\
\text { RM902 }\end{array}$ & 40.4 & 3 & 2 & 4 & 4.00 & 40.87 & 1.90 & 48.0 & 0.0 & \\
\hline 11 & $\mathrm{MQTL}_{8.2}$ & 8 & $\begin{array}{l}\text { RM339- } \\
\text { RM210 }\end{array}$ & & & 2 & 15 & 7.50 & 14.95 & 1.90 & 132.0 & 0.5 & \\
\hline 12 & $\mathrm{MQTL}_{10.1}$ & 10 & $\begin{array}{l}\text { RM244- } \\
\text { ME5_16 }\end{array}$ & 61.8 & 4 & 2 & 4 & 13.00 & 6.50 & 5.30 & 825.0 & 2.0 & \\
\hline 13 & $\mathrm{MQTL}_{10.2}$ & 10 & $\begin{array}{l}\text { RM596- } \\
\text { RM304 }\end{array}$ & & & 3 & 16 & 15.00 & 23.72 & 2.60 & 112.0 & 0.6 & \\
\hline 14 & $\mathrm{MQTL}_{12.1}$ & 12 & $\begin{array}{l}\text { RM277- } \\
\text { RM260 }\end{array}$ & 21.2 & 1 & 4 & 28 & 4.20 & 1.79 & 0.70 & 178.3 & 2.3 & 1 \\
\hline
\end{tabular}


identified at a confidence interval of $95 \%$ on seven chromosomes, and meta-analysis successfully reduced the total QTL by 63\% (Figures. 2, 3, 4, 5). The meta-QTL identified on each chromosome varied from 1 to 4 .
There were four meta-QTL on chromosome 1; two on chromosomes 2, 3, 8 and 10; and one each on chromosomes 4 and 12 . The phenotypic variance of the metaQTL varied from $4 \%$ to $28 \%$. At 10 of the 14 meta-

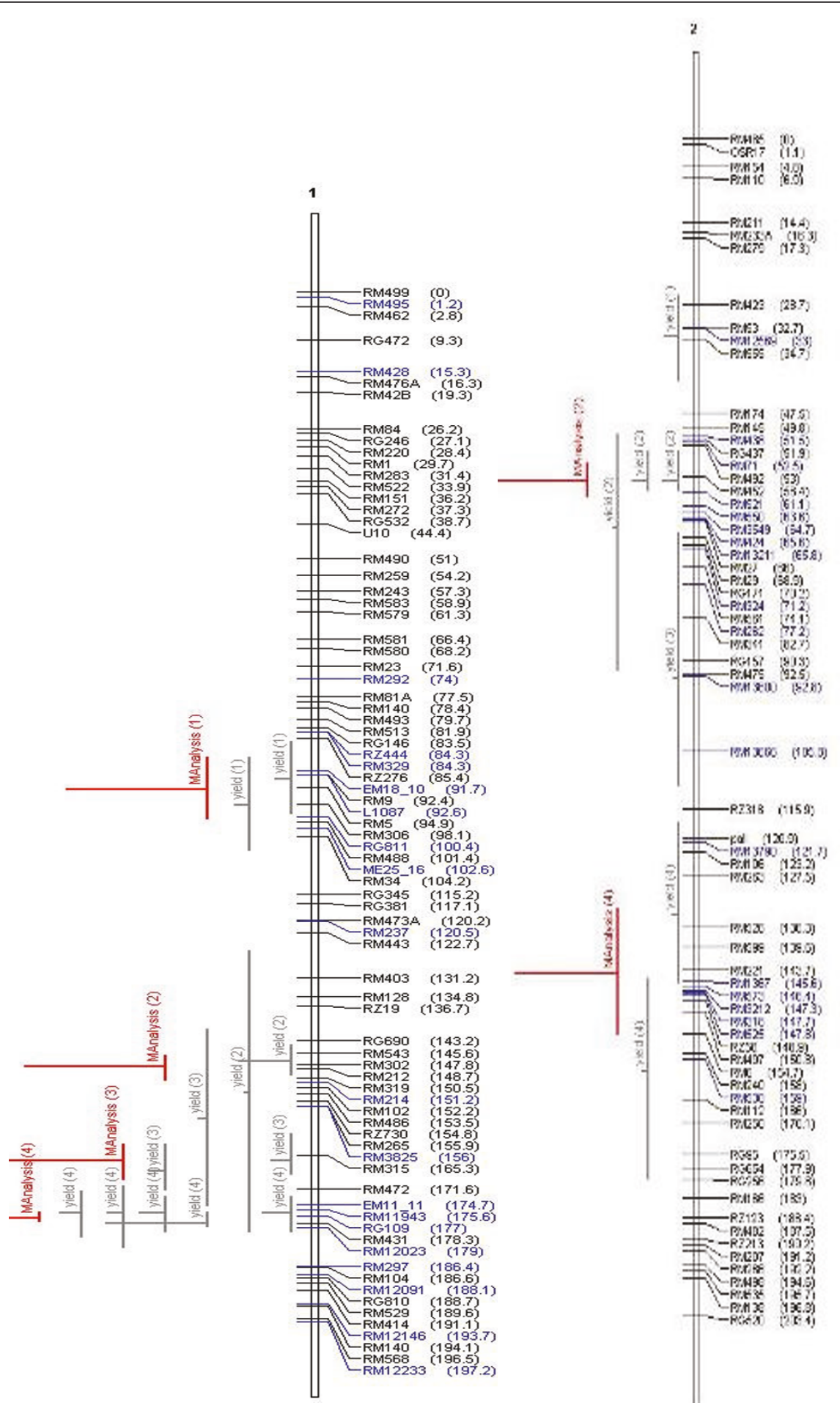

Figure 2 Meta-QTLs identified on chromosomes 1 and 2 by Meta- analysis of reported yield QTLs. The picture shows the Meta-QTLS on chromosomes 1 and 2. Vertical lines on the left of chromosomes indicate the confidence interval, horizontal lines indicate the variance, MQTL are in red. Markers and genetic distance (cM) are shown on the right of chromosomes. 


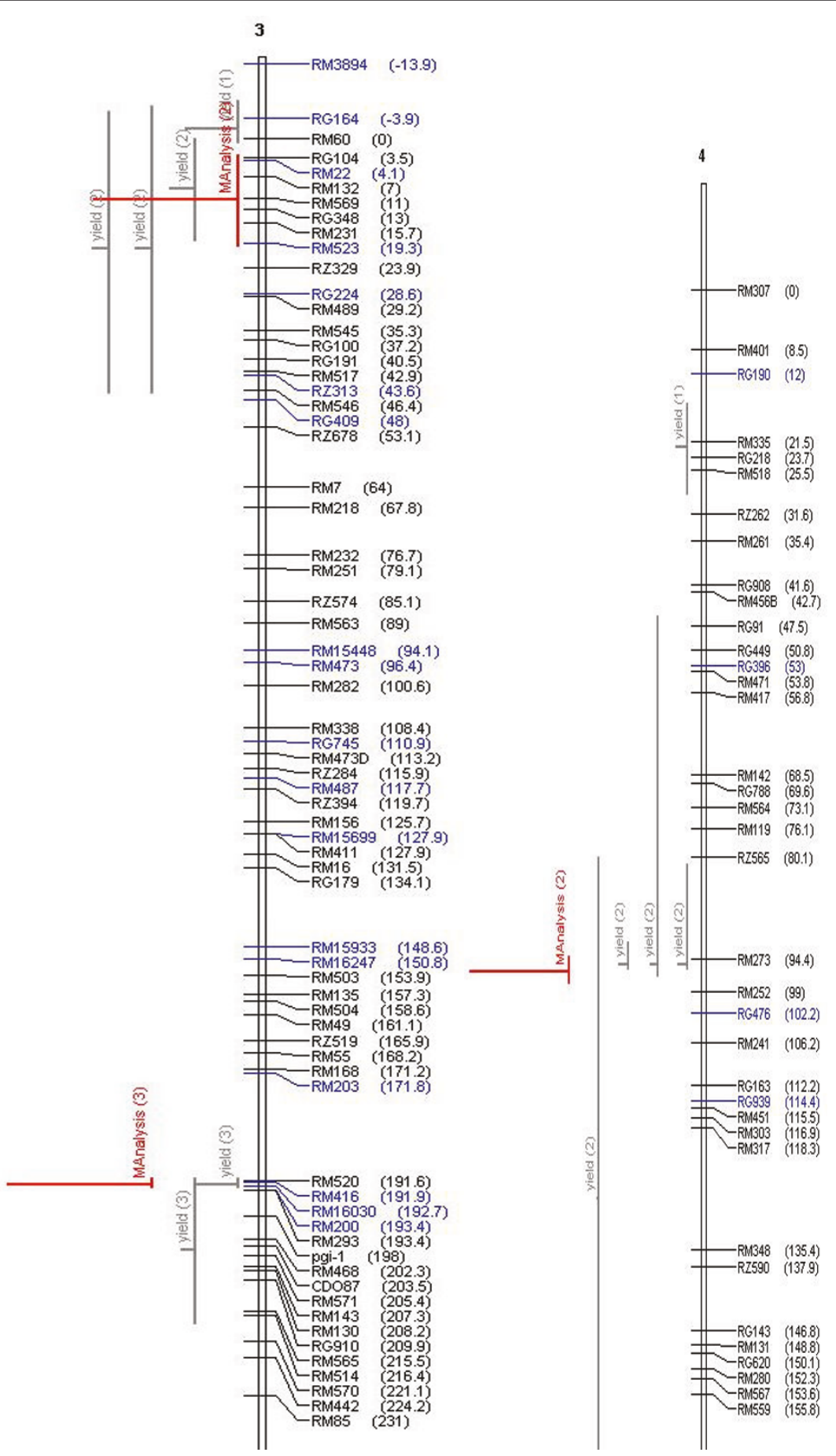

Figure 3 Meta-QTLs identified on chromosomes 3 and 4 by Meta- analysis of reported yield QTLs. The picture shows the Meta-QTLS on chromosomes 3 and 4 . Vertical lines on the left of chromosomes indicate the confidence interval, horizontal lines indicate the variance, MQTL are in red. Markers and genetic distance (cM) are shown on the right of chromosomes.

QTL, the mean phenotypic variance was more than $10 \%$. In general, the confidence intervals at most of the metaQTL were narrower than their respective original QTL. At nine loci on chromosomes 1,2, 3, 4, 10, and 12, meta-QTL were narrower than the mean of their initial
QTL. However, at five loci, the meta-QTL were broader than the mean of the initial QTL. The confidence intervals of the meta-QTL varied from $2.4 \mathrm{cM}$ between the marker intervals RG109 and RM431 on chromosome 1 to $40.8 \mathrm{cM}$ between the marker intervals RM337 and 


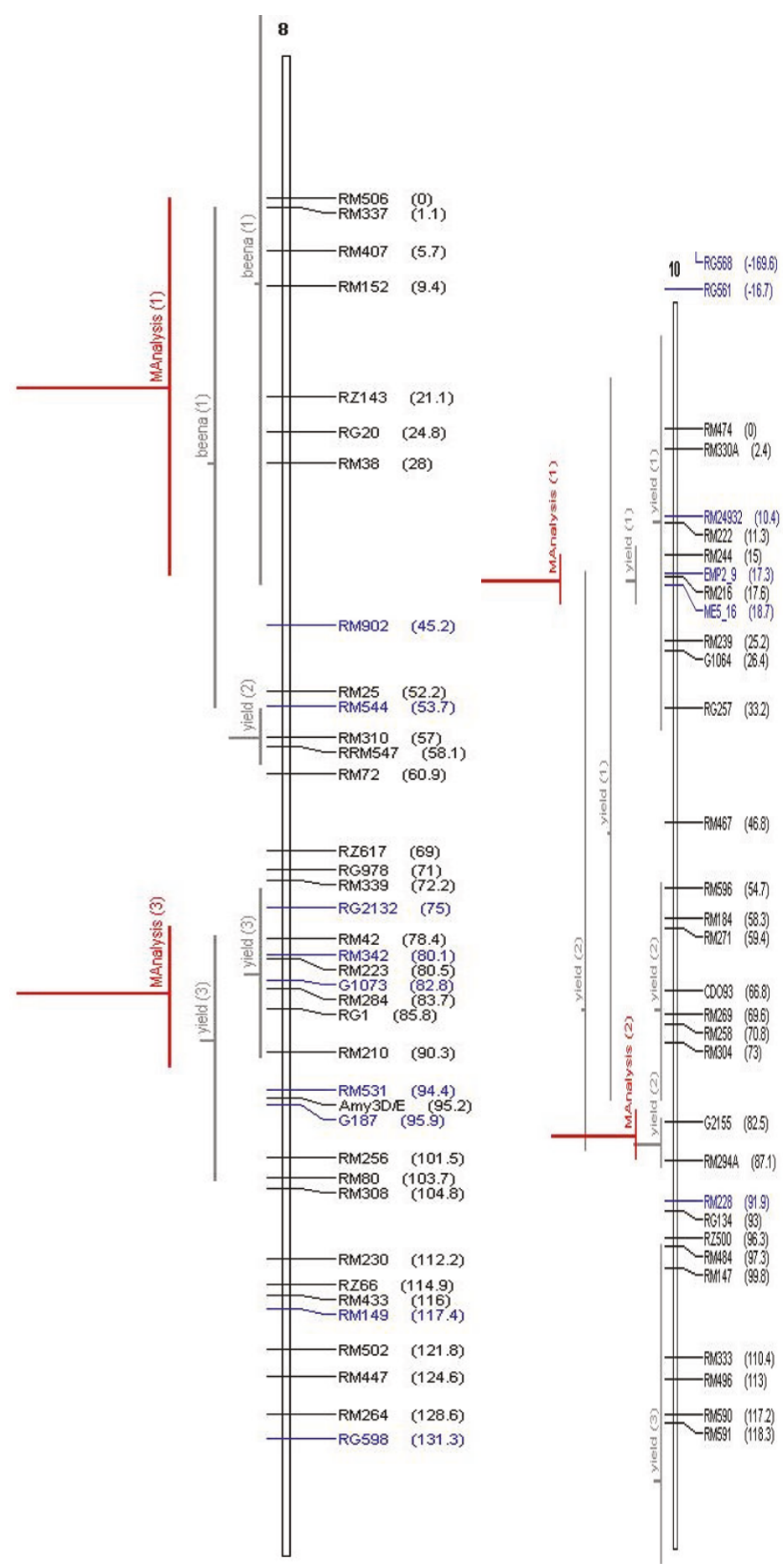

Figure 4 Meta-QTLs identified on chromosomes 8 and 10 by Meta- analysis of reported yield QTLs. The picture shows the Meta-QTLS on chromosomes 8 and 10. Vertical lines on the left of chromosomes indicate the confidence interval, horizontal lines indicate the variance, MQTL are in red. Markers and genetic distance (cM) are shown on the right of chromosomes.

RM902 on chromosome 8. At two regions, meta- $\mathrm{QTL}_{1.4}$ $\left(\mathrm{MQTL}_{1.4)}\right.$ and $\mathrm{MQTL}_{12.1}$, the CI declined to around $2 \mathrm{cM}$. The physical intervals of the meta-QTL varied from $0.16 \mathrm{Mb}$ to $5.3 \mathrm{Mb}$. Three meta-QTL were less than $500 \mathrm{~kb}$. The meta-QTL regions with small genetic and physical intervals are useful in MAS. It is significant to see that seven QTL that had less than $1.3 \mathrm{Mb}$ intervals also had a genetic interval of around $6 \mathrm{cM}$ with a 


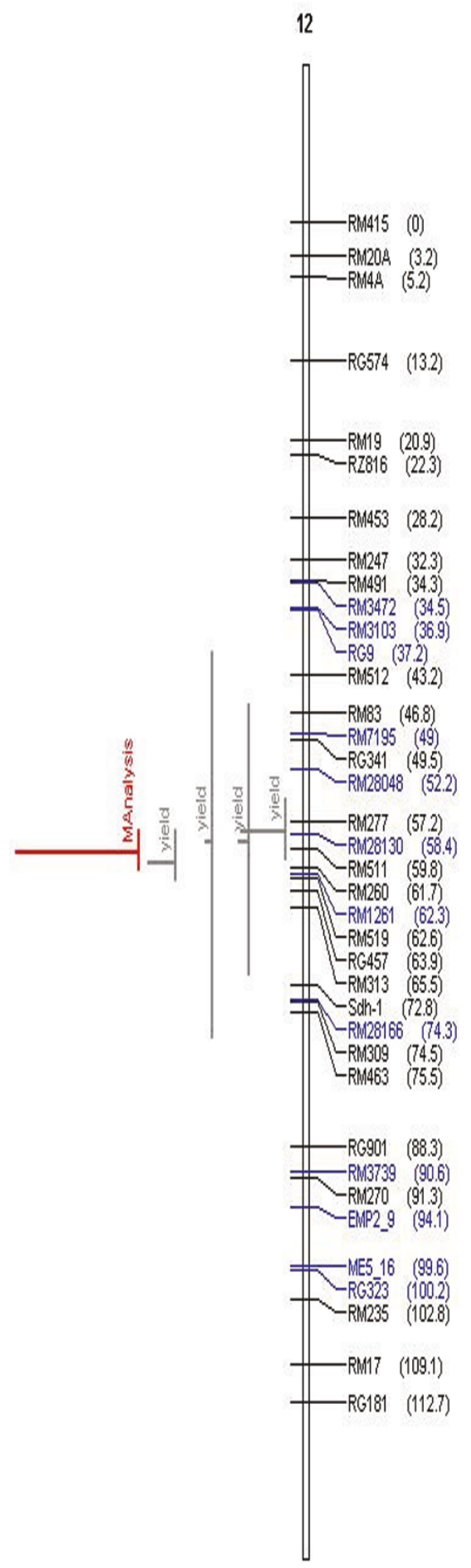

Figure 5 Meta-QTLs identified on chromosome 12 by Meta- analysis of reported yield QTLs. The picture shows the Meta-QTLs on chromosome 12. Vertical lines on the left of chromosomes indicate the confidence interval, horizontal lines indicate the variance, MQTL are in red. Markers and genetic distance (cM) are shown on the right of chromosomes. 
phenotypic variance of more than $10 \%$ (Figure 6). Three of these meta-QTL were on chromosome 1 and one each on chromosomes 2, 3 and 12 . The physical intervals of MQTL $1.2, \mathrm{MQTL}_{1.3}$, and MQTL 1.4 were less than $400 \mathrm{~kb}$, that of $\mathrm{MQTL}_{12.1}$ was $700 \mathrm{~kb}$, and those of $\mathrm{MQTL}_{3.2}, \mathrm{MQTL}_{4.1}$, and $\mathrm{MQTL}_{2.1}$ were $1 \mathrm{Mb}, 1.3 \mathrm{Mb}$, and $1.2 \mathrm{Mb}$, respectively. $\mathrm{MQTL}_{1.2}, \mathrm{MQTL}_{3.2}$, and MQTL $_{12.1}$ had phenotypic variance of more than $20 \%$. The seven MQTL regions with small genetic and physical intervals are important regions for MAS, fine mapping, candidate gene identification, and functional analysis. These QTL can be introgressed in popular rice mega-varieties to develop drought-tolerant and highyielding lines. In addition to meta-analysis of QTL, the markers linked to the 12 major-effect QTL for grain yield were also validated on a panel of drought-tolerant lines to confirm their presence in larger set of lines. It is notable that major-effect QTL $D T Y_{12.1}$ was present in $85 \%$ of the lines. $D T Y_{3.2}, D T Y_{4.2} D T Y_{1.1}, D T Y_{8.1}$, and $D T Y_{1.2}$ were present in more than $50 \%$ of the lines (Figure 7). The amplification of the RM523 and RM11943 peak markers of $D T Y_{3.2}$ and $D T Y_{1.1}$ in a set of 92 drought tolerant panel lines is presented in Additional File 3. The result indicates the presence of at least one of the major-effect grain yield QTL in the drought panel lines. In general, the major-effect QTL identified for grain yield under drought have a genetic gain of $10 \%$ to $30 \%$, with a yield advantage of around 150 to $500 \mathrm{~kg} / \mathrm{ha}$ over recipient parents. However, considering practical benefit to farmers, the development of drought-tolerant rice varieties with a yield advantage of at least 1 ton/ha could be the desired target for rice breeders. The marker-aided QTL pyramiding of the major-effect MQTL identified in this study can be considered as an option for achieving this target.

A comparison was made between the meta-QTL identified in this study with the meta-QTL identified for root traits in two earlier studies $[9,10]$. It is very interesting to note that $\mathrm{MQTL}_{1.2}, \mathrm{MQTL}_{2.2}, \mathrm{MQTL}_{3.1}$,

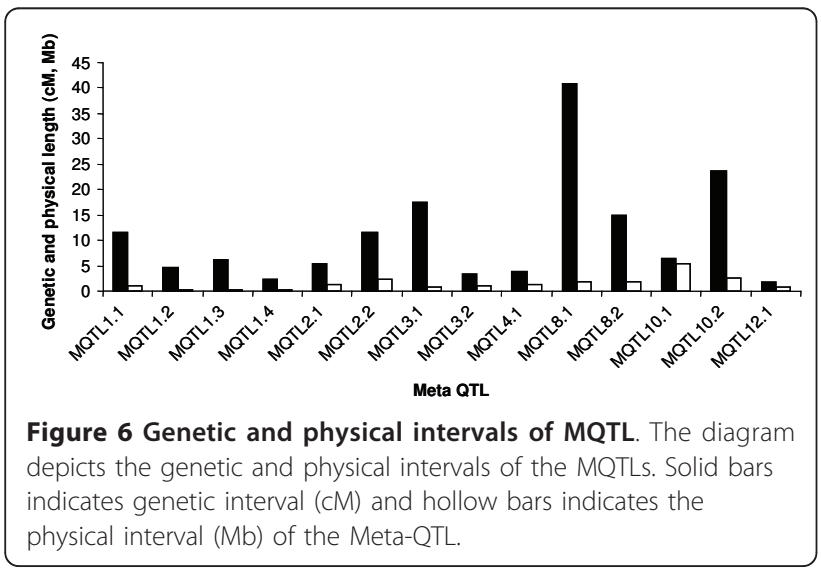

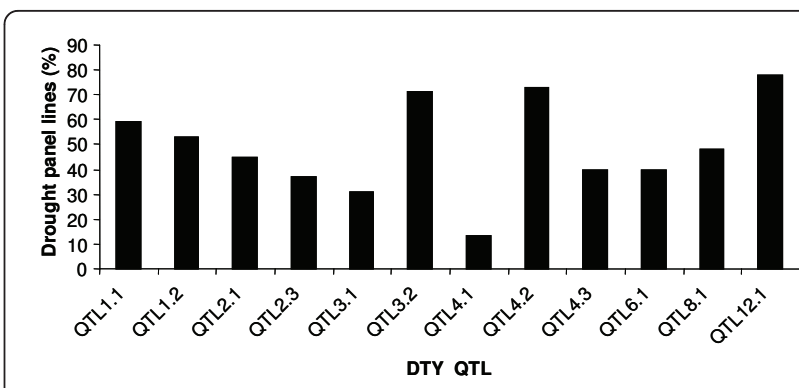

Figure 7 Frequency of drought grain yield QTL in drought panel lines. The diagram depicts frequency of major effect drought grain yield QTLs in a drought panel consisting of 92 lines.

MQTL $_{4.1}$, and MQTL $\mathrm{M}_{8.2}$ coincided with QTL clusters for root and leaf morphology traits associated with drought tolerance/avoidance in rice [9]. All the 14 independent meta-QTL coincided with at least one metaQTL identified for root traits under drought [10]. Earlier studies on meta-analysis of QTL for root traits $[9,10]$ and blast resistance in rice [12], fusarium head blight resistance in wheat [15], flowering time in maize [16], nematode resistance in soybean [14], and lint fiber length in cotton [13] identified precise and concise meta-QTL. Meta-QTL were also used to deduce candidate genes and were recommended for MAS in some of these studies.

\section{Comparative genomics of MQTL}

The existence of an evolutionary relationship among the grass families is a well-known fact. The syntenic relationship can be used to identify the homologous regions among these species, which in turn is useful in defining their role in plant growth, development, and adaptation across species. We compared meta-QTL regions for synteny in other cereal crops. The major-effect MQTL $\mathrm{M}_{1.4}$ was also found in maize on chromosome 3 near marker $m s u 2$, in wheat on chromosome $4 \mathrm{~B}$ near marker Rht-b1, and in barley on chromosome $6 \mathrm{H}$ near marker Bmac0316, while major-effect MQTL 3.2 was also found in maize on chromosome 1 near marker Umc107a (Figure 8). All these markers were linked to grain yield under drought in their respective crops. The largest parts of chromosomes 1 and 3 of rice have a syntenic relation with chromosomes 3 and 1 of maize, so their respective homologous QTL were also found on the corresponding chromosomes. An interesting observation is that, near the $s d 1$ locus on chromosome 1 of rice, QTL for grain yield under drought were identified most frequently. $S d 1$ is a major locus responsible for semidwarf plant stature in rice and its corresponding locus in wheat is $R h t-b 1$ on chromosome 4B. MQTL 1.4 is near the $s d 1$ locus and also on its corresponding locus $R h t-b 1$ in wheat, major QTL for grain yield under drought were detected. 

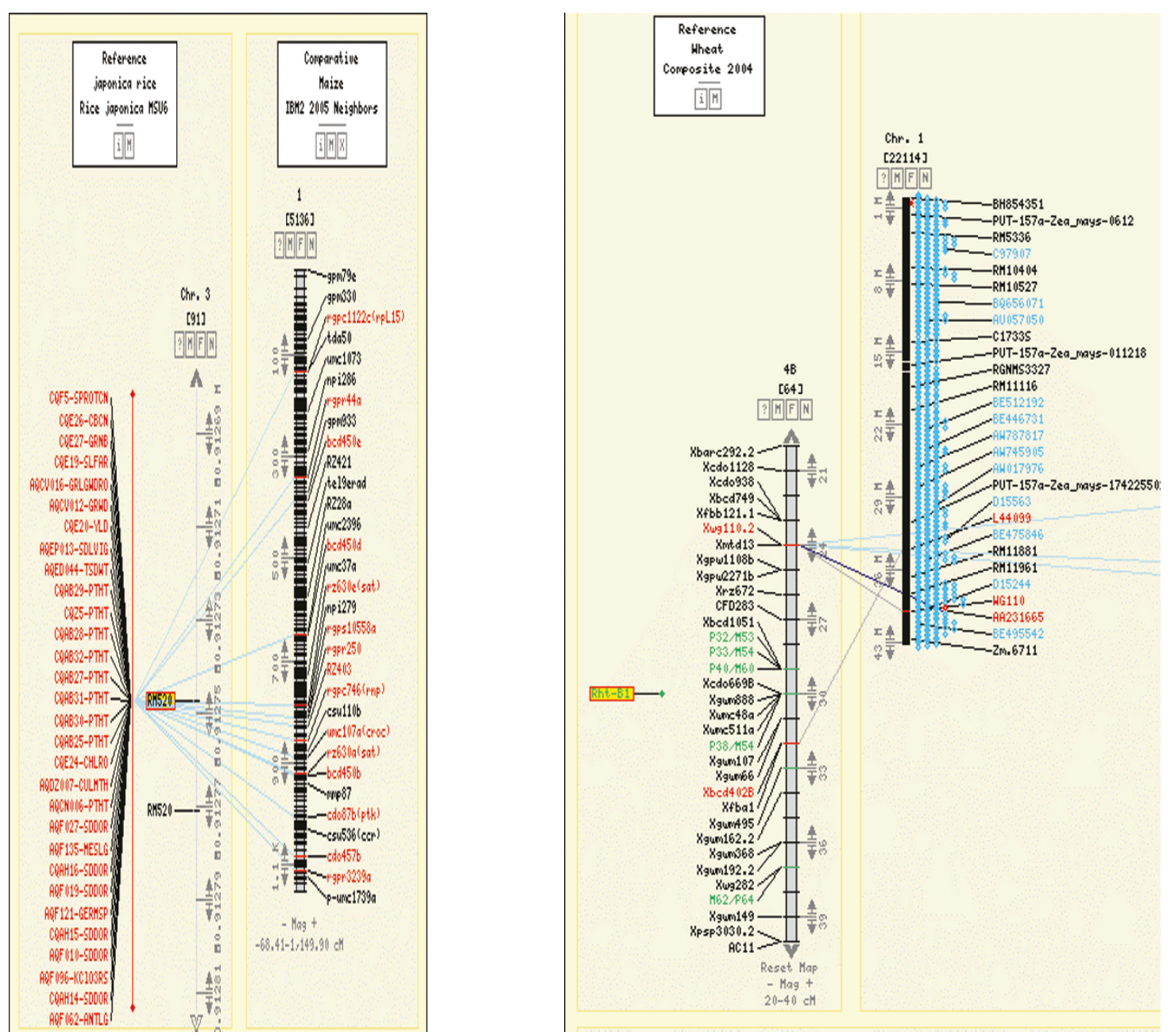

Figure 8 Comparative map of MQTL 1.4 in rice with its corresponding grain yield QTL near $\boldsymbol{R} h \boldsymbol{t}$ - $\boldsymbol{b} 1$ in wheat. The picture shows the comparative location of major effect Meta-QTL for grain yield under drought in rice MQTL 1.4 on a wheat genetic map.

\section{Gene content analysis and identification of candidate genes}

Meta QTL with precise and narrow confidence intervals are useful in short listing the candidate genes. Using the annotated gene information available in the rice database, the genes present in the 14 meta-QTL regions were analyzed by comparative genomics approach and candidate genes were shortlisted. The short-listed candidate genes can be further confirmed by transgenic approaches by loss or gain of function studies. Most of the genes present in the MQTL were genes for hypothetical and expressed proteins, pseudo genes, genes for signal transduction, and transposable elements. However, there were many annotated genes/gene families that were common across the MQTL regions; these are probable candidate genes for yield under drought. It was found that three kinds of genes frequently occurred together in these regions. The genes/gene families were stress-inducible genes, growth and development-related genes, and sugar transportrelated genes. Table 3 lists the important genes underlying MQTL for grain yield under drought. In six MQTL with less than a $1 \mathrm{Mb}$ region, LRR kinase, leucine zipper, cell division-controlling proteins, sugar transport protein-like genes, no apical meristem $(N A M)$, pentatricopeptide repeat proteins, cytokinin oxidase, F-box proteins, AP2-domain containing proteins, and zinc-finger transcription factors were present. The candidacy of these genes for yield and yield traits has already been proved in rice and other crops. Cytochrome P450 has a role in bassinosteroid homeostasis and had an influence on leaf angle leading to increased yield in rice [26,27]. Pentatricopeptide repeats are present in the promoter region of $R f$ genes, which restore fertility and also play a role in embryogenesis in Arabidopsis [28,29]. Zinc-finger (AN1-like)-like proteins are known to be involved in stress tolerance. Zinc-finger protein in rice are induced 
Table 3 Candidate genes reported in the identified MQTL region

\begin{tabular}{|c|c|c|c|c|}
\hline $\begin{array}{l}\text { S. } \\
\text { no. }\end{array}$ & MQTL & $\begin{array}{l}\text { Candidate genes (no. within } \\
\text { MQTL) }\end{array}$ & Candidate genes & $\begin{array}{l}\text { Candidate genes (no. in } \\
\text { total) }\end{array}$ \\
\hline 1 & $\mathrm{MQTL}_{1.1}$ & 1 & Calcineurin-related phosphoesterase-like & 14 \\
\hline 2 & & 2 & ERECTA-like kinase 1-like & 35 \\
\hline 3 & & 3 & Putative ankyrin-kinase & 69 \\
\hline 4 & & 4 & Putative NAC transcription factor & 135 \\
\hline 5 & & 5 & Putative pectin acetylesterase precursor & 139 \\
\hline 6 & & 6 & Putative signal recognition particle & 160 \\
\hline 7 & & 7 & QUAKING isoform 5-like & 179 \\
\hline 8 & & 8 & Tetratricopeptide repeat (TPR)-containing protein-like & 193 \\
\hline 9 & $\mathrm{MQTL}_{1.2}$ & 1 & ABC transporter subunit-like & 1 \\
\hline 10 & & 2 & F-box domain-containing protein-like & 39 \\
\hline 11 & & 3 & Glutaredoxin-like & 43 \\
\hline 12 & & 4 & Leucine zipper protein-like & 51 \\
\hline 13 & & 5 & Lustrin A-like & 52 \\
\hline 14 & & 6 & Nodulin-like protein & 57 \\
\hline 15 & & 7 & Ovate family protein-like & 59 \\
\hline 16 & & 8 & Pentatricopeptide repeat (PPR)-containing protein-like & 60 \\
\hline 17 & & 9 & Protein kinase-like & 66 \\
\hline 18 & & 10 & Putative auxin-independent growth promoter & 76 \\
\hline 19 & $\mathrm{MQTL}_{1.3}$ & 1 & Cell wall protein-like & 21 \\
\hline 20 & & 2 & Cytochrome P450 monooxygenase & 30 \\
\hline 21 & & 3 & F-box domain-containing protein-like & 39 \\
\hline 22 & & 4 & hAT dimerisation domain-containing protein-like & 45 \\
\hline 23 & & 5 & HGWP repeat-containing protein-like & 48 \\
\hline 24 & & 6 & Leucine zipper protein-like & 51 \\
\hline 25 & & 7 & Nucleoporin-like protein & 58 \\
\hline 26 & & 8 & Pentatricopeptide repeat (PPR)-containing protein-like & 60 \\
\hline 27 & & 9 & pr1-like protein & 65 \\
\hline 28 & & 10 & Sucrose-phosphatase-like protein & 192 \\
\hline 29 & & 11 & Zinc knuckle domain-containing protein-like & 206 \\
\hline 30 & $\mathrm{MQTL}_{1.4}$ & 1 & Polyprotein-like & 64 \\
\hline 31 & & 2 & Putative aspartic proteinase nepenthesin II & 74 \\
\hline 32 & & 3 & Putative cytokinin oxidase & 97 \\
\hline 33 & & 4 & Putative lectin-like receptor kinase 1:1 & 130 \\
\hline 34 & & 5 & Putative vacuole membrane protein 1 & 172 \\
\hline 35 & $\mathrm{MQTL}_{2.1}$ & 1 & Ethylene-responsive family protein-like & 37 \\
\hline 36 & & 2 & Putative cytochrome P450 & 94 \\
\hline 37 & & 3 & Putative DREPP2 protein & 106 \\
\hline 38 & & 4 & Putative F-box protein & 111 \\
\hline 39 & & 5 & Putative flavin-containing monooxygenase & 114 \\
\hline 40 & & 6 & Putative GTP-binding protein & 120 \\
\hline 41 & & 7 & Putative kaurene synthase & 128 \\
\hline 42 & & 8 & Putative pentatricopeptide repeat (PPR)-containing protein & 140 \\
\hline 43 & & 9 & Putative sugar transporter & 164 \\
\hline 44 & & 10 & Aquaporin & 7 \\
\hline 45 & $\mathrm{MQTL}_{2.2}$ & 1 & Cell wall protein & 21 \\
\hline 46 & & 2 & Dehydration-responsive family protein-like & 33 \\
\hline 47 & & 3 & F-box protein-like & 39 \\
\hline 48 & & 4 & Growth-regulating factor 1-like & 44 \\
\hline 49 & & 5 & HGWP repeat-containing protein-like & 48 \\
\hline 50 & & 6 & Pentatricopeptide repeat (PPR)-containing protein-like & 60 \\
\hline 51 & & 7 & Putative anther-specific protein & 70 \\
\hline
\end{tabular}


Table 3 Candidate genes reported in the identified MQTL region (Continued)

\begin{tabular}{|c|c|c|c|c|}
\hline 52 & & 8 & Putative anthocyanin biosynthetic gene regulator & 72 \\
\hline 53 & & 9 & Putative basic-helix-loop-helix transcription factor & 77 \\
\hline 54 & & 10 & Putative cell division control protein & 85 \\
\hline 55 & & 11 & Putative cold acclimation protein & 90 \\
\hline 56 & & 12 & Putative CRT/DRE binding factor 1 & 93 \\
\hline 57 & & 13 & Putative cytochrome P450 & 94 \\
\hline 58 & & 14 & Putative growth-regulating factor 1 & 119 \\
\hline 59 & & 15 & Putative high-mobility group protein & 124 \\
\hline 60 & & 16 & Putative pectin methylesterase & 138 \\
\hline 61 & & 17 & Putative photoperiod-independent early flowering & 145 \\
\hline 62 & & 18 & Putative sexual differentiation process protein & 158 \\
\hline 63 & & 19 & Root-specific protein & 184 \\
\hline 64 & & 20 & Sexual differentiation process protein-like & 187 \\
\hline 65 & & 21 & Trehalose-6-phosphate phosphatase & 194 \\
\hline 66 & & 22 & UDP-glycosyltransferase-like & 194 \\
\hline 67 & & 23 & Vesicle-associated membrane protein-like & 199 \\
\hline 68 & & 24 & Zinc finger (C3HC4-type RING finger)-like & 201 \\
\hline 69 & $\mathrm{MQTL}_{3.1}$ & 1 & Adapitin protein-like & 4 \\
\hline 70 & & 2 & Cell division control protein 2-like & 18 \\
\hline 71 & & 3 & Cyclin 2 interactor-like & 26 \\
\hline 72 & & 4 & F-box domain-containing protein-like & 39 \\
\hline 73 & & 5 & Flavanone 3-hydroxylase-like & 40 \\
\hline 74 & & 6 & HGWP repeat-containing protein-like & 48 \\
\hline 75 & & 7 & MADS-box transcription factor & 53 \\
\hline 76 & & 8 & NAC domain-containing protein-like & 54 \\
\hline 77 & & 9 & Photomorphogenic & 63 \\
\hline 78 & & 10 & Putative callose synthase 1 & 81 \\
\hline 79 & & 11 & Putative cell cycle switch protein & 84 \\
\hline 80 & & 12 & Putative cell division control protein 2 & 86 \\
\hline 81 & & 13 & Putative cytochrome p450 & 94 \\
\hline 82 & & 14 & Putative dihydrodipicolinate reductase & 103 \\
\hline 83 & & 15 & Putative dihydrofolate synthetase & 104 \\
\hline 84 & $\mathrm{MQTL}_{3.2}$ & 1 & ABC transporter-like protein-like & 2 \\
\hline 85 & & 2 & c-type cytochrome synthesis 1 & 25 \\
\hline 86 & & 3 & Pentatricopeptide repeat (PPR)-containing protein-like & 60 \\
\hline 87 & & 4 & Pherophorin-dz1 protein-like & 62 \\
\hline 88 & & 5 & Putative cleavage stimulation factor subunit 1 -like protein & 89 \\
\hline 89 & & 6 & Putative cold acclimation protein & 90 \\
\hline 90 & & 7 & Putative peroxidase & 142 \\
\hline 91 & & 8 & Putative phytochrome C & 146 \\
\hline 92 & & 9 & Putative prolamin & 148 \\
\hline 93 & & 10 & Putative prolyl 4-hydroxylase & 149 \\
\hline 94 & & 11 & Putative protein kinase SPK-2 & 150 \\
\hline 95 & & 12 & Putative protein phosphatase $2 \mathrm{C}$ & 151 \\
\hline 96 & & 13 & Putative UDP-glucose 6-dehydrogenase & 171 \\
\hline 97 & & 14 & Putative zinc-finger protein & 177 \\
\hline 98 & & 15 & Receptor protein kinase & 181 \\
\hline 99 & & 16 & Senescence downregulated leo1 & 185 \\
\hline 100 & $\mathrm{MQTL}_{4.1}$ & 1 & Auxin-related protein-like & 11 \\
\hline 101 & & 2 & Cell division cycle & 20 \\
\hline 102 & & 3 & Cytochrome c oxidase & 28 \\
\hline 103 & & 4 & Hydroxyproline-rich glycoprotein & 49 \\
\hline
\end{tabular}


Table 3 Candidate genes reported in the identified MQTL region (Continued)

\begin{tabular}{|c|c|c|c|c|}
\hline 104 & & 5 & Integral membrane transporter-like & 50 \\
\hline 105 & & 6 & Lustrin A-like & 52 \\
\hline 106 & & 7 & Protoporphyrinogen IX oxidase & 67 \\
\hline 107 & & 8 & Putative calcium-binding protein & 79 \\
\hline 108 & & 9 & Putative cell cycle checkpoint protein MAD2 homolog & 83 \\
\hline 109 & & 10 & Putative chitinase & 88 \\
\hline 110 & & 11 & Putative CONSTANS-like protein & 92 \\
\hline 111 & & 12 & Putative ER33 protein & 108 \\
\hline 112 & & 13 & Putative LRR receptor-like kinase & 131 \\
\hline 113 & & 14 & Putative salt-tolerance protein & 154 \\
\hline 114 & & 15 & Stress-inducible protein & 191 \\
\hline 115 & & 16 & Zinc finger (C3HC4-type RING finger)-like protein & 202 \\
\hline 116 & $\mathrm{MQTL}_{4.2}$ & 1 & ABC-1-like & 3 \\
\hline 117 & & 2 & Auxin response factor & 9 \\
\hline 118 & & 3 & Calcium-dependent protein kinase & 15 \\
\hline 119 & & 4 & CCAAT-box binding factor HAP5 & 17 \\
\hline 120 & & 5 & Cytochrome P450 monooxygenase & 29 \\
\hline 121 & & 6 & Cytokinin-induced apoptosis inhibitor 1 & 32 \\
\hline 122 & & 7 & Heat shock protein binding & 47 \\
\hline 123 & & 8 & HGWP repeat-containing protein & 48 \\
\hline 124 & & 9 & Pentatricopeptide repeat (PPR)-containing protein & 60 \\
\hline 125 & & 10 & Pherophorin-C1 protein precursor-like & 61 \\
\hline 126 & & 11 & Putative calcium-dependent protein kinase & 80 \\
\hline 127 & & 12 & Putative dehydration-responsive element-binding protein & 101 \\
\hline 128 & & 13 & Putative ethylene response factor & 109 \\
\hline 129 & & 14 & Putative floricaula & 115 \\
\hline 130 & & 15 & Putative flowering locus D & 116 \\
\hline 131 & & 16 & Putative growth-regulating factor & 118 \\
\hline 132 & & 17 & Putative IAA24 & 125 \\
\hline 133 & & 18 & Putative inositol 1,3,4,5,6-pentakisphosphate 2-kinase & 126 \\
\hline 134 & & 19 & Putative jasmonate O-methyltransferase & 127 \\
\hline 135 & & 20 & Putative late embryogenesis abundant protein & 129 \\
\hline 136 & & 21 & Putative wall-associated kinase 1 & 175 \\
\hline 137 & & 22 & RCP1 (ROOT CAP 1)-like & 180 \\
\hline 138 & & 23 & Stress-related-like protein interactor-like & 190 \\
\hline 139 & & 24 & Wall-associated protein kinase-like & 200 \\
\hline 140 & & 25 & Zinc finger (C3HC4-type RING finger)-like & 201 \\
\hline 141 & $\mathrm{MQTL}_{8.1}$ & 1 & Heat shock protein & 46 \\
\hline 142 & & 2 & Vesicle-associated membrane protein & 197 \\
\hline 143 & & 3 & Auxin efflux carrier protein-like & 8 \\
\hline 144 & & 4 & Cell division control protein-like & 19 \\
\hline 145 & & 5 & Cellulose synthase-1-like protein & 22 \\
\hline 146 & & 6 & CLAVATA1 receptor kinase (CLV1)-like protein & 23 \\
\hline 147 & & 7 & CONSTANS-like protein & 24 \\
\hline 148 & & 8 & Cytochrome b5-like & 27 \\
\hline 149 & & 9 & Ethylene-responsive elongation factor EF-Ts precursor-like & 36 \\
\hline 150 & & 10 & F-box domain-containing protein-like & 39 \\
\hline 151 & & 11 & Germin protein type 1 & 42 \\
\hline 152 & & 12 & HGWP repeat-containing protein-like & 49 \\
\hline 153 & & 13 & NAC2 protein-like & 55 \\
\hline 154 & & 14 & Nam-like protein & 56 \\
\hline 155 & & 15 & Nodulin-like protein & 57 \\
\hline
\end{tabular}


Table 3 Candidate genes reported in the identified MQTL region (Continued)

\begin{tabular}{|c|c|c|c|c|}
\hline 156 & & 16 & Pentatricopeptide repeat (PPR)-containing protein-like & 60 \\
\hline 157 & & 17 & Polyprotein-like protein & 64 \\
\hline 158 & & 18 & Putative $\mathrm{ABC}$ transporter & 68 \\
\hline 159 & & 19 & Putative anthocyanin 5-aromatic acyltransferase & 71 \\
\hline 160 & & 20 & Putative AP2/EREBP transcription factor LEAFY PETIOLE & 73 \\
\hline 161 & & 21 & $\begin{array}{l}\text { Putative CCAAT box binding factor/transcription factor } \\
\text { Hap2a }\end{array}$ & 82 \\
\hline 162 & & 22 & Putative chaperone GrpE & 87 \\
\hline 163 & & 23 & Putative cold shock protein-1 & 91 \\
\hline 164 & & 24 & Putative cytokinin-regulated kinase 1 & 98 \\
\hline 165 & & 25 & Putative death receptor interacting protein & 99 \\
\hline 166 & & 26 & Putative DEFECTIVE IN ANTHER DEHISCENCE1 & 100 \\
\hline 167 & & 27 & Putative farnesylated protein & 110 \\
\hline 168 & & 28 & Putative fertility restorer homolog & 113 \\
\hline 169 & & 29 & Putative MADS-box protein & 132 \\
\hline 170 & & 30 & Putative male fertility protein & 133 \\
\hline 171 & & 31 & Putative nucleoporin & 137 \\
\hline 172 & & 32 & Putative pherophorin & 143 \\
\hline 173 & & 33 & Putative senescence-associated protein & 155 \\
\hline 174 & & 34 & Putative osmatic embryogenesis receptor-like kinase 1 & 178 \\
\hline 175 & & 35 & Putative sexual differentiation process protein isp4 & 159 \\
\hline 176 & & 36 & Putative starch synthase & 161 \\
\hline 177 & & 37 & Putative stress-responsive gene & 162 \\
\hline 178 & & 38 & Putative teosinte branched 1 protein & 166 \\
\hline 179 & & 39 & Putative trehalose-6-phosphate synthase & 170 \\
\hline 180 & & 40 & Putative vesicle-associated membrane associated protein & 173 \\
\hline 181 & & 41 & Putative wall-associated kinase & 174 \\
\hline 182 & & 42 & Ripening-related protein-like & 182 \\
\hline 183 & & 43 & Root cap protein 1-like & 183 \\
\hline 184 & & 44 & Senescence-associated protein-like & 186 \\
\hline 185 & & 45 & Stress-inducible protein-like & 189 \\
\hline 186 & & 46 & Zinc finger-like protein & 204 \\
\hline 187 & MQTL 8.2 & 1 & AP2 domain transcription factor-like & 6 \\
\hline 188 & & 2 & Auxin-induced protein-related-like protein & 10 \\
\hline 189 & & 3 & F-box protein family-like protein & 39 \\
\hline 190 & & 4 & Pentatricopeptide repeat (PPR)-containing protein-like & 60 \\
\hline 191 & & 5 & Putative calcineurin B subunit & 78 \\
\hline 192 & & 6 & Putative cytochrome P450 monooxygenase & 95 \\
\hline 193 & & 7 & Putative male fertility protein & 133 \\
\hline 194 & & 8 & Putative NAC domain protein & 134 \\
\hline 195 & & 9 & Putative senescence-associated protein & 155 \\
\hline 196 & & 10 & Putative stromal cell-derived factor 2 precursor & 163 \\
\hline 197 & & 11 & Putative temperature stress-induced lipocalin & 165 \\
\hline 198 & & 12 & Putative teosinte branched1 protein & 166 \\
\hline 199 & & 13 & Putative tethering factor & 167 \\
\hline 200 & & 14 & Putative trehalose-6-phosphate synthase & 170 \\
\hline 201 & & 15 & Somatic embryogenesis receptor kinase-like protein & 188 \\
\hline 202 & & 16 & Zinc finger protein-like & 204 \\
\hline 203 & $\mathrm{MQTL}_{10.1}$ & 1 & Aminotransferase-like & 5 \\
\hline 204 & & 2 & Putative gibberellin-regulated protein & 117 \\
\hline 205 & & 3 & Putative peptide transporter 1 & 141 \\
\hline 206 & & 4 & Putative serine threonine kinase & 157 \\
\hline
\end{tabular}


Table 3 Candidate genes reported in the identified MQTL region (Continued)

\begin{tabular}{|c|c|c|c|c|}
\hline 207 & & 5 & Putative wall-associated kinase 4 & 176 \\
\hline 208 & & 6 & ABC transporter-like & 1 \\
\hline 209 & $\mathrm{MQTL}_{10.2}$ & 1 & Calcineurin B-like protein & 13 \\
\hline 210 & & 2 & Calcium-dependent protein kinase, isoform 1 (CDPK 1) & 16 \\
\hline 211 & & 3 & Cytochrome p450-like & 31 \\
\hline 212 & & 4 & Dehydration-responsive family protein-like & 33 \\
\hline 213 & & 5 & Elicitor-like protein & 34 \\
\hline 214 & & 6 & Ethylene-responsive protein-like & 38 \\
\hline 215 & & 7 & F-box protein-like & 39 \\
\hline 216 & & 8 & Fringe-related protein-like & 41 \\
\hline 217 & & 9 & Pentatricopeptide repeat (PPR)-containing protein-like & 60 \\
\hline 218 & & 10 & Putative anther-specific protein & 70 \\
\hline 219 & & 11 & Putative auxin response factor 10 & 75 \\
\hline 220 & & 12 & Putative cytokinin dehydrogenase & 96 \\
\hline 221 & & 13 & Putative DEFECTIVE IN ANTHER DEHISCENCE1 & 100 \\
\hline 222 & & 14 & Putative dehydration-induced protein & 102 \\
\hline 223 & & 15 & Putative DRE binding factor 2 & 105 \\
\hline 224 & & 16 & Putative drought-inducible protein & 107 \\
\hline 225 & & 17 & Putative fertility restorer & 112 \\
\hline 226 & & 18 & Putative hairy meristem & 121 \\
\hline 227 & & 19 & Putative heat shock factor RHSF5 & 122 \\
\hline 228 & & 20 & Putative hexose carrier protein HEX6 & 123 \\
\hline 229 & & 21 & Putative NAM (no apical meristem) gene & 136 \\
\hline 230 & & 22 & Putative pollen-specific kinase partner protein & 147 \\
\hline 231 & & 23 & Putative root cap-specific glycine-rich protein & 152 \\
\hline 232 & & 24 & Putative salt-induced MAP kinase 1 & 153 \\
\hline 233 & & 25 & Putative senescence-associated protein $\mathrm{DH}$ & 156 \\
\hline 234 & & 26 & Putative tonoplast membrane integral protein & 168 \\
\hline 235 & & 27 & Putative trehalose-6-phosphate phosphatase & 169 \\
\hline 236 & & 28 & Putative zinc finger protein & 177 \\
\hline 237 & & 29 & Ripening-related protein-like & 182 \\
\hline 238 & & 30 & Senescence-associated protein-like & 186 \\
\hline 239 & & 31 & Stress-inducible protein-like & 189 \\
\hline 240 & & 32 & Tetratricopeptide repeat (TPR)-containing protein-like & 193 \\
\hline 241 & & 33 & Universal stress protein-like & 195 \\
\hline 242 & & 34 & Vacuolar protein-sorting $13 \mathrm{C}$ protein-like & 196 \\
\hline 243 & & 35 & Vesicle-associated membrane associated protein-like & 198 \\
\hline 244 & & 36 & Zinc finger (HIT type)-like & 203 \\
\hline 245 & $M Q T L_{12.1}$ & 1 & Calcineurin B-like & 12 \\
\hline 246 & & 2 & Cell wall protein-like & 21 \\
\hline 247 & & 3 & HGWP repeat-containing protein-like & 48 \\
\hline 248 & & 4 & Hydroxyproline-rich glycoprotein-like & 49 \\
\hline 249 & & 5 & Putative pherophorin-dz1 protein & 144 \\
\hline 250 & & 6 & Zinc knuckle-containing protein-like & 205 \\
\hline
\end{tabular}

after different types of stresses, namely, cold, desiccation, salt, submergence, heavy metals, and mechanical injury. Over expression of the zinc-finger gene in transgenic tobacco conferred tolerance of cold, dehydration, and salt stress at the seed germination/seedling stage [30,31]. Fbox proteins play an important role in floral development and stress tolerance. In addition, F-box proteins appear to serve as the key components of the machinery involved in regulating plant growth and development throughout the plant's life cycle and their expression is influenced by light and abiotic stresses [32]. Leucine zippers are a class of transcription factor involved in ABAindependent stress tolerance. Over expression of $O s b$ ZIP23 in rice triggered clusters of genes regulating stress 
adaptations [33]. The no apical meristem gene (NAM) plays an important role in the growth and development of meristematic tissue. The root-specific expression of this gene resulted in enhanced root growth and improved drought tolerance in rice [34]. The other important genes that harbored the meta-QTL were the ERECTA and $D R E B$ genes. ERECTA is a leucine-rich repeat receptorlike kinase gene known for its influence on inflorescence development, stomatal density, epidermal cell expansion, and mesophyll cell proliferation. This gene is mainly involved in transpiration efficiency and enhanced drought response [35]. DREB is a well-known transcription factor that is induced by drought and it activates many down stream stress-responsive genes to ultimately improve the drought and chilling tolerance of rice [36]. Some of these short-listed genes can be considered as positional candidate genes that determine grain yield under drought. However, it is also well known that yield and adaptability to stress are complex in nature and highly negatively correlated. The QTL/genes for these two are often co-located. Even though individual genes have been proved to regulate yield under controlled drought experiments, a well-coordinated response of many genes is essential for drought tolerance under field conditions. This is evident from the presence of three different groups of gene clusters in most of the meta-QTL regions.

\section{Conclusions}

Meta-analysis of grain yield QTL is an effective approach in identifying concise and precise consensus QTL. The seven meta-QTL identified with small genetic and physical intervals could be useful in MAS/pyramiding. Validation of the major-effect QTL confirmed the consistency of the major-effect grain yield QTL under drought in different drought-tolerant panel lines. The comparative genomics approach to identify the consistency of drought grain yield QTL across species revealed the conservation of some of the loci, indicating their evolutionary significance. The presence of gene clusters in the meta-QTL indicates that a well-coordinated response of many genes is essential to achieve drought tolerance under field conditions.

\section{Additional material}

Additional File 1: Details of the markers used for QTL validation This file contains the list of major effect QTLs for grain yield under drought and peak markers of the QTLs. Primer sequence, product size of the markers and annealing temperatures ( $\mathrm{Tm}$ ) used for amplifying the markers.

Additional File 2: Drought panel lines for QTL validation. This table shows the list of drought panel lines and type of the breeding material. These lines were used for validating the major effect QTLs for grain yield under drought.
Additional File 3: Amplification of RM523 and RM11943 peak markers of $Q T L_{3.2}$ and $Q T L_{1.1}$ in a set of 92 drought tolerant panel lines. The gel picture shows the amplication of RM523 and RM11943 peak markers of $Q T L_{3.2}$ and $Q T L_{1.1}$ in a set of 92 drought tolerant panel lines.

\section{Acknowledgements}

Financial support to this study was provided by the Bill \& Melinda Gates Foundation, USA.

\section{Authors' contributions}

AK conceived the idea of Meta- analysis, QTL validation and comparative genomics of grain yield QTL under drought. BPMS compiled and analyzed the data, carried out the QTL validation and comparative genomics. SD helped in data compilation and analysis. BPMS, PV, SD, HUA and AK were responsible for drafting and editing the manuscript. All authors have read and approved the final manuscript.

Received: 9 December 2010 Accepted: 16 June 2011

Published: 16 June 2011

\section{References}

1. Lanceras CJ, Pantuwan G, Jongdee B, Toojinda T: Quantitative trait loci associated with drought tolerance at reproductive stage in rice. Plant Physiology 2004, 135:384-399.

2. Venuprasad R, Dalid CO, Del Valle M, Zhao D, Espiritu M, Sta Cruz MT, Amante M, Kumar A, Atlin GN: Identification and characterization of largeeffect quantitative trait loci for grain yield under lowland drought stress in rice using bulk-segregant analysis. Theoretical and Applied Genetics 2009, 120:177-190

3. Wassmann R, Jagadish SVK, Sumfleth K, Pathak H, Howell G, Ismail A, Serraj R, Redoña E, Singh RK, Heuer S: Regional vulnerability of climate change impacts on Asian rice production and scope for adaptation. Advances in Agronomy 2009, 102:91-133.

4. Bates BC, Kundzewicz ZW, Wu S, Palutikof JP: Climate change and water. In technical paper of the Intergovernmental Panel on Climate Change IPCC Secretariat, Geneva; 2008, 210 [http://www.ipcc.ch/].

5. Bernier J, Kumar A, Ramaiah V, Spaner D, Atlin GN: A large-effect QTL for grain yield under reproductive-stage drought stress in upland Rice. Crop Science 2007, 47:507-518.

6. Podlich DW, Winkler CR, Cooper M: Mapping as you go: an effective approach for marker-assisted selection of complex traits. Crop Science 2004, 44:1560-1571.

7. Collins NC, Tardieu F, Tuberosa R: Quantitative trait loci and crop performance under abiotic stress: Where do we stand? Plant Physiology 2008, 147:469-486

8. Swamy BPM, Sarla N: Yield enhancing QTLs from wild species. Biotechnology Advances 2008, 26:106-111.

9. Khowaja FS, Norton GJ, Courtois B, Price AH: Improved resolution in the position of drought-related QTLs in a single mapping population of rice by meta-analysis. BMC Genomics 2009, 10:276.

10. Courtois B, Ahmadi N, Khowaja F, Price A, Rami JF, Frouin J, Hamelin C, Ruiz M: Rice root genetic architecture: meta-analysis from a QTL database improves resolution to a few candidate genes. Rice 2009, 2:115-128.

11. Goffinet B, Gerber S: Quantitative trait loci: a meta-analysis. Genetics 2000, 155:463-473.

12. Ballini E, Morel JB, Droc G, Price AH, Courtois B, Nottehem JL, Tharreau DA: Genome wide meta analysis of rice blast resistance genes and quantitative trait loci provides new insights into partial and complete resistance. Molecular and Microbe Interaction 2008, 21:859-868.

13. Rong J, Feltus FA, Waghmare VN, Pierce GJ, Chee PW, Draye X, Saranga Y, Wright RJ, Wilkins TA, May OL, Smith CW, Gannaway JR, Wendel JF, Paterson AH: Meta-analysis of polyploid cotton QTL shows unequal contributions of sub genomes to a complex network of genes and gene clusters implicated in lint fiber development. Genetics 2007, 176:2577-2588. 
14. Guo B, Sleper DA, Lu P, Shannon JG, Nguyen HT, Arelli PR: QTLs associated with resistance to soybean cyst nematode in soybean meta-analysis of QTL locations. Crop Science 2006, 46:202-208.

15. Loffler M, Schon CC, Miedaner T: Revealing the genetic architecture of FHB resistance in hexaploid wheat (Triticum aestivum L.) by QTL metaanalysis. Molecular Breeding 2009, 23:473-488.

16. Chardon F, Virlon B, Moreau L, Falque M, Joets J, Decousset L, Murigneux A Charcosset A: Genetic architecture of flowering time in maize as inferred from quantitative trait loci meta-analysis and synteny conservation with rice genome. Genetics 2004, 168:2169-2185.

17. Hao Z, Li X, Liu X, Xie C, Li M, Zhang D, Zhang S: Meta-analysis of constitutive and adaptive QTL for drought tolerance in maize. Euphytica 2010, 174:165-177.

18. Lanaud C, Fouet O, Clement D, Boccara M, Risterucci AM, Maharaj SS, Legavre T, Argout X: A meta-QTL analysis of disease resistance traits of Theobroma cacao L. Molecular Breeding 2009, 24:361-374.

19. Temnykh S, DeClerck G, Lukashova A, Lipovich L, Cartinhour S, McCouch SR: Computational and experimental analysis of microsatellite in rice (Oryza sativa $\mathrm{L}$.): frequency, length variation, transposon associations and genetic marker potential. Genome Research 2001, 1:1441-1452

20. Darvasi A, Soller M: A simple method to calculate resolving power and confidence interval of QTL map location. Behavioural Genetics 1997, 27:125-132.

21. Hirotugu A: A new look at the statistical model identification. IEEE Transactions on Automatic Control 1974, 19:716-723.

22. Beena : Studies on physio-morphological traits and genetic markers associated with drought response in rice (O. sativa). Tamil Nadu Agricultural University, Coimbatore, India; 2005, PhD thesis.

23. Prashant V: Development and morpho-molecular analysis of Swarna (Oryza sativa L.) introgression lines for drought tolerance. Veer Bahadur Singh Purvanchal University, Jaunpur, Uttar Pradesh, India; 2010.

24. Price AH: Believe it or not, QTLs are accurate. Trends in Plant Science 2006 11:213-216.

25. Ashikari M, Matsuoka M: Identification, isolation and pyramiding of quantitative trait loci for rice breeding. Trends in Plant Science 2006, 11:344-350.

26. Ashikari M, Sakakibara H, Lin S, Ymamoto T, Takashi T, Nishimura A, Angeles ER, Qian Q, Kitano H, Matsuoka M: Cytokinin oxidase regulates rice grain production. Science 2005, 309:741-745.

27. Sakamoto T, Morinaka Y, Ohnishi T, Sunohara H, Fujioka S, Tanaka MU, Mizutani M, Sakata K, Takatsuto S, Yoshida S, Tanaka H, Kitano H, Matsuoka M: Erect leaves caused by brassinosteroid deficiency increase biomass production and grain yield in rice. Nature Biotechnology 2005, 24:105-109.

28. Bentolila S, Alfonso AA, Hanson MR: A pentatricopeptide repeatcontaining gene restores fertility to cytoplasmic male-sterile plants. Proceedings of the National Academy of Sciences, USA 2002, 99:10887-10892.

29. Daniel A, Cushing E, Nancy R, Daniel R, Daniel M: Arabidopsis emb175 and other ppr knockout mutants reveal essential roles for pentatricopeptide repeat (PPR) proteins in plant embryogenesis. Planta 2005, 221:424-436.

30. Mukhopadhyay A, Vij S, Tyagi AK: Overexpression of a zinc-finger protein gene from rice confers tolerance to cold, dehydration, and salt stress in transgenic tobacco. Proceedings of the National Academy of Sciences, USA 2004, 101:6309-6314

31. Wang L, Xu Y, Zhang C, Ma Q, Joo SH, Kim SK, Xu Z, Chong K: OsLIC, a novel $\mathrm{CCCH}$-type zinc finger protein with transcription activation, mediates rice architecture via brassinosteroids signaling. PLOS One 2008, 3:e3521.

32. Jain M, Nijhawan A, Arora R, Agarwal P, Ray S, Sharma P, Kapoor S, Tyagi AK, Khurana JP: F-box proteins in rice: genome-wide analysis, classification, temporal and spatial gene expression during panicle and seed development, and regulation by light and abiotic stress. Plant Physiology 2007, 143:1467-1483.

33. Xiang $Y$, Tang $N$, Du H, Ye H, Xiong L: Characterization of OsbZIP23 as a key player of the basic leucine zipper transcription factor family for conferring abscisic acid sensitivity and salinity and drought tolerance in rice. Plant Physiology 2008, 48:1938-1952.

34. Jeong JS, Kim YS, Baek KH, Jung H, Ha SH, Choi YD, Kim M, Reuzeau C, Kim JK: Root-specific expression of OsNAC10 improves drought tolerance and grain yield in rice under field drought conditions. Plant Physiology 2010, 153:185-197.
35. Masle J, Gilmore SR, Farquhar GD: The ERECTA gene regulates plant transpiration efficiency in Arabidopsis. Nature 2005, 436:866-870.

36. Ito Y, Katsura K, Maruyama K, Taji T, Kobayashi M, Seki M, Shinozaki K, Shinozaki KY: Functional analysis of rice DREB1/CBF-type transcription factors involved in cold-responsive gene expression in transgenic rice. Plant and Cell Physiology 2006, 47:141-153.

37. Chandra Babu R, Nguyen BD, Chamarerk V, Shanmugasundaram $P$, Chezhian P, Jeyaprakash P, Ganesh SK, Palchamy A, Sadasivam S, Sarkarung S, Wade LJ, Nguyen HT: Genetic analysis of drought resistance in rice by molecular markers: association between secondary traits and field performance. Crop Science 2003, 43:1457-1469.

38. Yue $B$, Xiong $L$, Xue W, Xing $Y$, Luo $L, X u C$ : Genetic analysis for drought resistance of rice at reproductive stage in field with different types of soil. Theoretical and Applied Genetics 2005, 111:1127-1136.

39. Zou GH, Mei HW, Liu HY, Liu GL, Hu SP, Yu XQ, Li MS, Wu JH, Luo LJ: Grain yield responses to moisture regimes in a rice population: association among traits and genetic markers. Theoretical and Applied Genetics 2005, 112:106-113.

40. Yue B, Xue W, Xiong L, Yu X, Luo L, Cui K, Jin D, Xing Y, Zhang Q: Genetic basis of drought resistance at reproductive stage in rice: separation of drought tolerance from drought avoidance. Genetics 2006, 172:1213-1228.

41. Gomez MS, Satheesh Kumar S, Jeyaprakash P, Suresh R, Biji KR, Boopathi NM, Price AH, Chandra Babu R: Mapping QTLs linked to physiomorphological and plant production traits under drought stress in rice (Oryza sativa L.) in the target environment. American Journal of Biochemistry and Biotechnology 2006, 2:161-169.

42. Kumar R, Venuprasad R, Atlin GN: Genetic analysis of rainfed lowland rice drought tolerance under naturally-occurring stress in eastern India: heritability and QTL effects. Field Crops Research 2007, 103:42-52.

doi:10.1186/1471-2164-12-319

Cite this article as: Swamy et al:: Meta-analysis of grain yield QTL identified during agricultural drought in grasses showed consensus. BMC Genomics 2011 12:319.

\section{Submit your next manuscript to BioMed Central and take full advantage of:}

- Convenient online submission

- Thorough peer review

- No space constraints or color figure charges

- Immediate publication on acceptance

- Inclusion in PubMed, CAS, Scopus and Google Scholar

- Research which is freely available for redistribution

Submit your manuscript at www.biomedcentral.com/submit
C) Biomed Central 